\title{
ANALISIS PENYIMPANAN BERAS MELALUI PERUM BULOG SUB DIVRE PEKALONGAN TERHADAP KESTABILAN HARGA
}

\author{
Restu Pambudi dan Yusuf Enril Fathurrohman* \\ Program Studi Agribisnis Fakultas Pertanian, Universitas Muhammadiyah Purwokerto \\ yusuf.enril@gmail.com
}

\begin{abstract}
Perum BULOG Pekalongan Sub-Divre is responsible not only for storing rice but also having responsibility for price stability. This study aims to determine the flow distribution of Bulog rice, rice criteria and the role of Perum BULOG Pekalongan Sub-Divre on price stability. The analytical method used is descriptive analysis and using primary and secondary data. The results showed that the Plot of Perum BULOG Pekalongan Sub-Divre did not differ from the central regulation, which used 3 channels (SATGAS AD DN, UPGB and Partners). The types of rice managed by Bulog are Raskin (medium) and commercial (premium) rice with applicable criteria. Meanwhile, to maintain the stability of rice prices, the Pekalongan Public Logistics Agency (Perum Bulog) conducts market operations at 10 distribution points and provides Raskin to Poor Households (RTM).
\end{abstract}

Kata Kunci : Perum Bulog, Pekalongan Sub-Divre, Storage

\section{PENDAHULUAN}

Beras merupakan makanan pokok yang banyak dikonsumsi oleh masyarakat Indonesia karena merupakan sumber karbohidrat tertinggi dengan kandungan gizi beras per 100 gr yaitu $360 \mathrm{kkal}$ energy, 6,6 gr protein, 0,58 gr lemak, dan 79,34 gr karbohidrat (Suliartini et al., 2011 dan Sediaoetama, 2006). Oleh karenan beras merupakan bahan pangan yang sangat penting dan utama bagi masyarakat Indonesia maka ketersediaan beras bagi masyarakat merupakan hal yang sangat fundamental untuk diperhatikan oleh negara.

Dalam rangka pemenuhan ketersediaan dan kestabilan harga beras, Negara telah menunjuk badan khusus yaitu Perum BULOG sebagai perusahaan umum milik negara yang bergerak di bidang logistik. Berdasarkan website resmi BULOG, diantara kegiatan BULOG yaitu menjaga Harga Dasar
Pembelian untuk gabah, stabilisasi harga khususnya harga pokok, menyalurkan beras untuk orang miskin (Raskin) dan pengelolaan stok pangan.

Keberadaan BULOG sendiri secara umum untuk menjaga kestabilan persediaan dan harga pangan yang dilatarbelakangi oleh peningkatan jumlah penduduk dimana juga terjadi peningkatan jumlah kebutuhan akan pangan. Diprediksi bahwa pada tahun 2035 jumlah penduduk Indonesia diperkirakan meningkat menjadi 305,7 Juta jiwa (BPS, 2018). Jumlah penduduk yang besar tentu saja harus diiringi dengan ketersediaan pangan yang stabil baik di tingkat Nasional maupun Regional. Oleh karena itu keberadaan BULOG sangat diperlukan dalam mengatur urusan logistik terlebih pada bahan pangan pokok.

Pada dasarnya Perum BULOG menerapkan manajemen rantai pasok dalam pengelolaan 
logistiknya. Pada manajemen rantai pasok strategi ideal yang utama yaitu fokus pada ketercapaian efisiensi dan kemampuan dalam mengatur kesesuaian untuk merespon permintaan konsumen (Chopra dan Meindl, 2007). Dalam penerapan untuk memenuhi kebutuhan konsumen di Indonesia terdapat banyak gudang perum BULOG yang cukup besar kapasitasnya salah satunya di perum BULOG Subdivisi Pekalongan. Secara umum terdapat beberapa gudang yang dibagi menjadi tipe $\mathrm{A}, \mathrm{B}$, dan $\mathrm{C}$ sebagai mana terdapat dipasal 73 bab 5 gudang. Gudang Perum Bulog Subdivisi Pekalongan termasuk ke dalam gudang tipe A karena memiliki kapasitas simpan lebih dari > 14.000 ton. Untuk tempat gudang tipe A terdapat di Munjung Agung/ Jalan raya Pantura, Larangan, Munjung Agung, Keramat, Tegal, Jawa Tengah 52181.

Dilengkapi dengan fasilitas gudang yang ada maka Perum BULOG Sub Divre Pekalongan bukan hanya menjadi penyimpan beras akan tetapi juga memiliki tanggung jawab terhadap kestabilan harga. Dalam hal penyimpanan, Perum BULOG sudah memiliki aturan dari pemerintah untuk beras lokal maupun luar negeri agar sesuai standar nasional dan untuk kestabilan harga. Perum BULOG melakukan obervasi terhadap suatu daerah dimana daerah tersebut dianggap terjadi kenaikan harga beras yang cukup tinggi. Untuk melakukan distribusi beras ini tentu saja BULOG harus mempunyai stok beras yang cukup agar harga beras dapat dikendalikan.
Pelaksanaan obeservasi juga dilakukan tahun ini oleh Perum BULOG Subdivisi Pekalongan. Kegiatan observasi dilakukan melalui pelaksanaan OP-CBP yang merupakan program kelanjutan sejak awal 2018. Setidaknya 7.590 ton beras telah disalurkan sejak Januari hingga Desember 2018. Kegiatan ini diharapkan dapat tetap menjaga konsumen dan tidak merugikan produsen.

Kendati telah melakukan berbagai kegiatan untuk menstabilkan ketersediaan dan harga beras namun secara umum menurut Trisilawaty, dkk (2011) melaporkan bahwa rantai pasok beras dan penggunaan gudang di Perum BULOG belum optimal. Lebih lanjut Perum BULOG dikatakan belum optimal dalam pengelolaan pangan nasional khususnya pada penggunaan kapasitas gudang (Tajuddin B dan Rahmat F, 2018).

Berdasarkan latar belakang tersebut maka diperlukan kajian yang bertujuan untuk mengetahui alur penyimpan beras bulog, kriteria beras dan peranan Perum BULOG Subdivisi Pekalongan terhadapa kestabilan harga.

\section{METODE PENELITIAN}

Penelitian dilaksanakan di Perum BULOG Subdivisi Pekalongan yang beralamatkan di Jalan Kolonel Sugiono No.139, Kemandungan, Tegal Barat, Kota Tegal, Jawa Tengah 52112. Penelitian ini dilakukan pada tahun 2019.

Dengan tenknik pengambilan data menurut Sugiyono (2013). 
1. Metode Observasi

Pengamatan langsung di perum bulog sub divisi pekalongan didampingi oleh juru timbang

2. Wawancara

Mendapat informasi secara langsung dari kepala gudang.

\section{Dokumentasi}

Mendapat informasi melalui keadaan kerja praktik secara langsung agar data terpercaya didampingi oleh pegawai dari KERANI.

\section{Pengambilan Data Sekunder}

Didapat dari tempat kerja praktik seperti jurnal, buku profil perusahan.

Untuk jenis data yang digunakan menurut Narimawati (2007):

\section{Data primer}

Data yang dilakuan dengan wawancara kepada karyawan gudang Perum Bulog Sub Divre Pekalogan beserta karyawan kantor pusat.

\section{Data skunder}

Merupakan data yang dapat memperkuat dalam rumusan masalah dalam ulasan kerja praktik dapat didukung dari literatur hasil jurnal, buku perusahaan maupun bidang terkait.

Metode analisis data menggukan analisis deskriptif menurut (Suparno dan Yunus ,2006: 48). Diaharapkan mampu menjelaskan permasalahan di perum bulog sub divisi pekalongan:

1. Alur penyimpanan beras di Perum BULOG Subdivisi Pekalongan Tentang bagaimana proses masuknya beras petani atau mitra kerja ke perum bulog.

2. Kriteria beras yang sesuai standar nasioal agar bisa masuk ke Perum BULOG Subdivisi Pekalongan Tentang kadar air,butir patah,butir menir dan derajat sosoh.

3. Peran Perum BULOG Subdivisi Pekalongan terhadap kestabilan harga Tentang langkah-langkah mengatasi kestabilan harga seperti oprasi pasar dan raskin

\section{HASIL DAN PEMBAHASAN}

\section{Alur Penyimpanan Beras}

Sistem dan prosedur penyimpanan dibuat berdasarkan keputusan direksi No. KD107/DO301/03/2009 tenggal 24 maret 2014 tentang peraturan pergudangan dilingkungan Perusahan umum badan logistik (BULOG). Dimana setiap kepala gudang berwenang dan bertangguang jawab untuk menerima, menyimpan, merawat dan menyerahkan beras yang dipercaya kepadanya sesuai ketentuan.

Dalam mengatasi masalah data beras broken dan kurang akurat maka dibentuklah alur penyimpanan beras dengan melalui tiga saluran dalam penyerapan produksi tani yaitu SATGAS ADA DN, Unit Pengolahan Gabah Dan Beras (UPGB), dan mitra kerja. Ketiga saluran tersebut membeli gabah langsung ke petani dengan patokan harga pokok penjualan (HPP).

Adapun mekanisme alur pengadaan dalam negeri dari pihak perum BULOG terhadap kantor pusat yaitu melalui sebuah Pengajuan Rencana Pengadaan Dalam Negeri (Prognosa) ke kantor pusat dengan rincian daerah 
perbulan. Rincian tersebut disertai dengan analisis defisit surplus produksi dan usulan perum sub divre untuk mendapatkan persetujuan kantor pusat. Kantor pusat kemudian memberikan sebuah intruksi kepada sub divre untuk melaksanakan pola umum kontraktor konvensional dan pola kemitraan melalui (UPGB). Selanjutnya Perum sub divre mengajukan kebutuhan L/C (letter of credits) dan sarana pengadaan ke kantor pusat kemudian perum sub divre menerima L/C dimana kantor pusat mengendalikan pengadaan dari perum bulog dilanjutkan dengan pembuatan rekapitulasi realisasi pengadaan per sub divre yang nantinya dikirim ke kantor pusat.

Alur pengadaan beras untuk beras dalam negeri dimulai dari kantor pusat Perum Bulog dengan adanaya L/C. L/C adalah sebuah cara pembayaran internasional yang memungkinkan eksportir menerima pembayaran tanpa menunggu berita dan memudahkan pihak yang berada didalamnya. Setelah Divre menerima perintah dari pusat kemudian mitra kerja membuat permohonan kontrak. Apabila kontrak diterima maka Divre akan mentukan jumlah, waktu dan tempat pelaksanaan pengadaan lalu melakukan pengiriman Surat Perintah Terima Barang (SPTB) kepada kepala gudang serta Surat Perintah Pemeriksaan (SSPK) untuk jasa pemeriksaan kualitas barang.

Tahap selanjutnya mitra kerja mengirim beras ke gudang berdasarkan kontrak yang sudah disetujui. Sebelum melakukan serah terima barang, petugas gudang dari KASI dan Juru timbang melakukan pengecekan apakah beras tersebut layak dan memenuhi kriteria. Apabila tidak layak maka gudang tidak bisa menerima dan sebaliknya apabila layak maka kepala gudang akan menerima beras dan membuat laporan penerimaan barang kepada pusat. Rekapan data yang dilaporkan ke pusat juga diberikan ke pda mitra kerja untuk juga mendapatkan Dokumen Bukti Penerimaan Barang (GD1M) dan Laporan Hasil Pemeriksaan Kualitas (LHPK).

Pada pelaksanaan alur pengadaan beras harus jelas dengan menjaga kondisi gudang dan melakukan penilaian yang tersturktur terhadap alur pengadaannya. Langkah ini dilakukan agar gudang tidak akan overstock dan mutu tetap terjaga.

\section{Kriteria Beras}

Perum Bulog Sub Divre Pekalongan menyerap beras dari petani dan beberapa mitra kerja. Terdapat dua jenis beras yang dikelola oleh Perum Bulog Sub Divre Pekalongan, yaitu beras raskin (medium) dan komersil (premium).

Tabel 1. Standar Nasional Kriteria beras raskin (beras medium)

\begin{tabular}{|c|c|c|c|}
\hline $\mathrm{o}$ & $\begin{array}{l}\text { Tipe } \\
\text { beras }\end{array}$ & Kriteria & $\%$ \\
\hline & Medium & Kadar Air & $<14 \%$ \\
\hline & Medium & Butir Patah & $<20 \%$ \\
\hline & Medium & Derajat Sosoh & $<90 \%$ \\
\hline & Medium & Butir Menir & $0-2 \%$ \\
\hline
\end{tabular}

Sumber : Data Primer Diolah 2019.

Standarisasi beras diperlukan untuk terjamin kualitas beras demi memastikan 
petani, pedangan dan konsumen mendapatkan keuntungan yang sama serta meningkatkan daya jual terhadapat beras lokal dengan luar negeri.

Tabel 2. Standar Nasional Kriteria beras premium

\begin{tabular}{|c|c|c|c|}
\hline $\mathrm{O}$ & $\begin{array}{l}\text { Tipe } \\
\text { beras }\end{array}$ & Kriteria & $\%$ \\
\hline & Premium & Kadar Air & $<14 \%$ \\
\hline & Premium & Butir Patah & $<15 \%$ \\
\hline & Premium & Derajat Sosoh & $<15 \%$ \\
\hline & Premium & Butir Menir & $0-2 \%$ \\
\hline
\end{tabular}

Sumber : Data Primer Diolah 2019.

Oleh karenanya Perum Bulog Sub Divre Pekalongan sangat memperhatikan mutu kuliatas beras bahkan dalam perawatanya selalu melakukan pengecekan setiap satu bulan sekali.

\section{Peran Perum BULOG Subdivisi Pekalongan}

Perum Bulog Subdivisi Pekalongan memiliki peran dalam menjaga kestabilan harga. Langkah-langkah yang diambil yaitu operasi pasar dan pembagian beras raskin.

\section{Operasi Pasar}

Perum Bulog Sub Divre Pekalongan dalam rangka mengatasi kestabilan harga di Kabupaten Tegal menggelar Operasi Pasar dengan penekanan penambahan jumlah beras yang ditawarkan kepada masyarakat. Mekanisme operasi pasar ini mengacu pada Permendag No.04/M-DAG/PER/1/2012 tentang penggunaan cadangan beras pemerintah (CBP) untuk stabilisasi harga. Operasi Pasar dilakukan Perum Bulog Sub Divre Pekalongan apabila dari pemerintah melayangkan surat untuk menggelar Operasi pasar. Alur operasi pasar yang dilaksanakan Perum Bulog Sub Divre Pekalongan dapat dilihat pada gambar 1 .

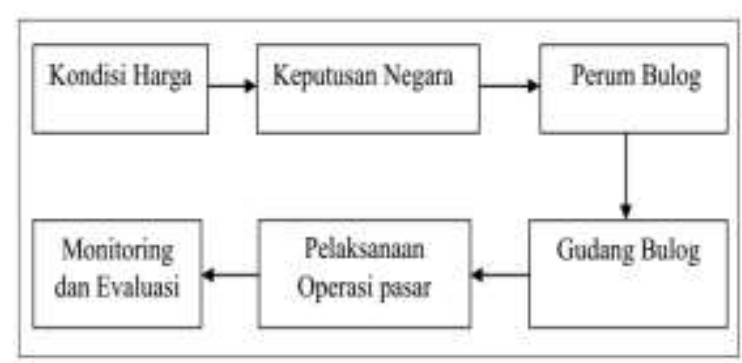

Gambar 1. Alur Operasi Pasar

Perum Bulog Sub Divre Pekalongan melakukan Operasi Pasar menuju 10 titik penyaluran seperti Pasar Pagi Kota Tegal, Pasar Kejambon, Pasar Langon, dan Pasar Martoloyo Kota Tegal. Untuk di luar kota tegal tersebar juga ke Pasar Trayeman, Pasar Banjaran, dan Pasar Balamoa. Di Kabupaten Pemalang disalurkan melalui Pasar Pagi Pemalang, sedangkan di Kabupaten Brebes dan Batang berada di di Pasar Bulakamba serta Pasar Batang.

\section{Beras Raskin}

Guna menangani masalah harga yang melambung tinggi dipasar. Penyaluran beras raskin dilakukan untuk membantu masyarakat miskin pada saat terjadinya kenaikan hargaharga bahan pangan yang terjadi biasanya di bulan menjelang ramadhan. Penyaluran beras raskin diberikan kepada masyarakat yang kurang mampu seperti Rumah tangga miskin (RMT) dengan menadapat $15 \mathrm{Kg}$ karung beras untuk 1 RTM. Dalam pengambilan beras raskin terdapat alur pelaksanaan dan dapat di lihat pada Gambar 2. 
Jumlah raskin yang disalurkan 9.676 ton diperuntukan bagi 630.590 RTM di tujuh Kabupaten/Kota meliputi kabupaten batang, pekalongan, pemalang, tegal, brebes. Diantaranya :

1. Kabupaten Brebes memiliki RTM 210.472

2. Kabupaten Pemalang memiliki RTM 132.779

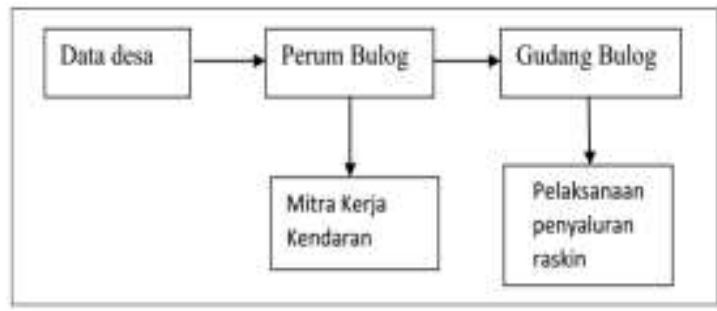

Gambar 2. Alur Pelaksanaan Beras Raskin.

3. Kabupaten Tegal memiliki RTM 102.809

1 RTM mendapatkan $15 \mathrm{~kg}$ untuk dengan harga Rp 1.600 dimana Kabupaten Brebes memiliki jumlah penerimaan beras tertinggi diantara Kabupaten/kota lain.

\section{KESIMPULAN}

Alur penyimpanan beras Perum Bulog SubDivre Pekalongan tidak berbeda dengan aturan pusat yaitu menggunakan 3 saluran (SATGAS AD DN, UPGB dan Mitra Kerja). Alur pengadaan beras sendiri disesuaikan dengan prosedur yang berlaku. Adapun jenis beras yang dikelola Perum Bulog yaitu beras raskin (medium) dan komersil (premium) dengan kriteria yang berlaku. Sedangkan untuk menjaga kestabilan harga beras, Perum Bulog Sub Divre Pekalongan melaksanakan operasi pasar di 10 titik penyaluran serta memberikan raskin kepada Rumah Tangga Miskin (RTM).

\section{DAFTAR PUSTAKA}

Badan Pembangunan Nasional. 2018. Pembangunan Kependudukan (disampaikan pada cara peluncuran buku Proyeksi Penduduk Indonesia Tahun 2015-2045. Jakarta.

Chopra, V.S., Meindl, P. 2007. Supply Chain Management: Strategy, Planning, and Operation, 3nd ed, Pearson Prentice Hall.

Narimawati, Umi. 2007. Riset Sumber Daya Manusia. Jakarta: Agung Media.

Sediaoetama, Achmad D. 2006. Ilmu Gizi untuk Mahasiswa dan Profesi. Jakarta: Dian Rakyat

Sugiyono.2013. Metode Penelitian Kuantitatif, Kualitatif dan $R \& D$. Bandung: Penerbit Alfabeta.

Suliartini, Ni Wayan S, Gusti R. S, teguh W., dan muhidin. 2011. Pengujian Kadar Antosianin Padi Gogo Beras Merah Hasil Koleksi Plasma Nutfah Sulawesi Tenggara. Crop Agro Vol. 4 (2): 43-48.

Suparno, Yunus,. 2006. Ketrampilan Dasar Menulis. Jakarta: Universitas Terbuka

Tajuddin Bantacut dan Rahmat Fadhil. 2018. Perum BULOG: Sebuah Gagasan Awal Application of LOGISTICTS 4.0 in Rice Supply Chain Management at Perum BULOG: An Initial Idea. Jurnal Pangan Vol. 27 No. 2.

Trisilawaty, C., Marimin, M., Achsani, N.A. 2014. Analisis Optimasi Rantai Pasok Beras dan Penggunaan Gudang Di Perum BULOG Divre DKI Jakarta. Jurnal Pangan, 20 (2): 177-197 